\title{
Corporate Governance in Jordan and Boardroom Diversity: A Critical Review of Literature
}

\author{
Ibrahim Mohammad Mkheimer \\ (PhD Candidate of Business Management) \\ Faculty of Economics and Management Sciences, \\ University Sultan Zainal Abidin, Terengganu, Malaysia
}

Doi: 10.19044/esj.2018.v14n10p359 URL:http://dx.doi.org/10.19044/esj.2018.v14n10p359

\begin{abstract}
This paper focuses on critically analyzing the present literature which discusses the Corporate Governance (CG) concept in Jordan and board diversity, and the potential benefits obtained from adopting this concept in different streams like its impact on the total organizational performance. The paper also aims to present related theories and empirical literature focused on the composition of corporates' boardroom and the role of its diversity in achieving their objectives such as competitive advantage. It also aims to determine the gaps and guidance for future studies. The review shows examples of basic theories, definition, methodologies, and certain industries deficiencies in previous studies and literature which limits the generalizability of their findings in specific environment, industry, and population. Finally, the study also presents implications on implementation, theory, and the best practice of Corporate Governance.
\end{abstract}

Keywords: Corporate governance, boardroom diversity, Jordan

\section{Introduction}

Corporate governance (CG) indicates the framework of large companies and the way these companies manage their businesses to achieve their strategic objectives, which focuses traditionally on maximizing shareholder's wealth. CG basically means the board of directors who govern the whole organization; the executive levels that make essential decisions; and the lower levels of management under them that carries out these decisions in a way to achieve the organization's interests. It is a fundamental matter in the society and can be a major objective for organizations at various levels (Shailer \& Greg, 2004). The governance demonstrates the rules, principles, and also distribute the rights and duties among several parties in the organizations (for instance, the board of directors, executives managers, 
shareholders, employees and other stakeholders) and forms the basics and processes in making decisions (OECD, 2004). CG as well includes the methods through which organization's objectives are determined and strives in the light of social, legal, and economic environment. Governance notion in the same vein consists of controlling the activities, plans, and actions of organizations, their representatives, and influential stakeholders (Ricker, 2009).

\section{Corporate Governance and Boardroom Diversity}

There is no single definition of CG due to its several perspectives which it is interpreted from. Zingales (1998) defined CG as "allocation of ownership, capital structure, managerial incentive schemes, takeovers, board of directors, pressure from institutional investors, product market competition, labour market competition, and organisational structure which can all be thought of as institutions that affect the process through which quasi-rents are distributed (p. 4)". The term "CG" has not been common. Few experts in the field of management have paid attention to this concept which generally characterizes the approach through which the companies are managed (O'Regan \& Oster, 2002). Moreover, this term seems to be used almost globally in guidance, organizing, and supervision. Garvey and Swan (1994) underlined that "governance determines how the firm's top decision makers actually administer such contracts (p. 139)". Shleifer and Vishny (1997) illustrate CG as "the ways in which suppliers of finance to corporations assure themselves of getting a return on their investment" (p.737). Oman (2001) characterized CG as a technique that indicates all types of organizations, either public or private, which involves rules, laws, and the business activities which dominate the relationship amongst the top managers and stakeholders. Lee (2006) defined corporate governance as "the formal mechanisms of directing, supervision, and control put in place within a company in order to monitor the decisions and actions of its senior managers and ensure these are compatible and consistent with the specific interest of shareholders and the various other interests of stakeholders who contribute to the operations of the company" ( $p$. 67). This definition refers to the responsibility of managers towards all stakeholders regarding directing, monitoring, and achieving organizational missions and visions. Responsibility, in this context, indicates that those managers are expected to give orderly records of their decisions and works.

Consequently, board diversity can be considered as one of the most competitive advantage sources (Cox \& Blake, 1991). Different studies have proved a positive relationship between diversity of board of directors and other dimensions like organizational performance (Barney, 1991); quality, board gender diversity and corporate dividend policy (Al-Rahahleh, 2017); cash conversion cycle (Al-Rahahleh, 2016); CG and compliance of public limited 
organisations (Alsharari, 2015); and CG, ownership structure and bank performance in Jordan (Al-Amarneh, 2014). However, this is because the success of the organization is directly connected with the upper level of management. The demographics of board of directors (BOD) and the variety of its members was indicated as the composition of these boards in light of various dimensions like gender, age, and educational basis and experience (Erhardt et al., 2003). Due to rapid changes and increase in the numbers of female employees, gender diversity has become an important stream for all in the organization. Board gender diversity indicates the existence of women in company boards of directors or percentage of women representation in these boards (Julizaerma \& Sori, 2012). Despite the increasing concern with corporate governance recently, most of these studies were conducted in developed countries and compared to studies in developing countries which were limited (Habbash, 2010). Empirical research describes the value of presence diversified directors in regards to gender, age, and nationality in high positions in the boards who are to be responsible for many corporate outcomes. The association among gender variety, and performance, for example, has been unsaturated and still needs further research. In addition, some studies have developed a positive and significant relationship between these factors (Julizaerma \& Sori, 2012).

All organizations are pursuing to obtain qualified members who have particular traits and skills in top managerial positions, such as chief executive officer (CEO), in their boards which might help in fostering their productivity. Bhagat et al. (2010) emphasized the importance of giving more attention to the educational background for board members in the hiring process. This basically is attributed to the fact that other measurements, like capabilities, may be very costly and difficult to measure. Gottesman and Morey (2006) stated that educational competences may be an evidence of brilliance, where most intelligent CEOs attempt to be the best in their field in comparison to their peers. Additionally, it is also worthy to note that outstanding management competencies does not always reflect a good level of education for managers. Latent characteristics, like leadership and creativity skills, may add a significant value. It is often noted that rapid improvement and high performance companies are controlled via people who have not acquired higher education (Gottesman \& Morey, 2006).

Bantel and Jackson (1989) proposed that highly competence of CEOs have an ability to manage information and adapt with key changes in the company. A number of researchers found that qualified managers with technical competences can grant company's departments with great resources (Barker \& Mueller, 2002). Similarly, Graham and Harvey (2002) opined that financial managers who hold Master of Business Administration (MBA) tends to be more effective in adopting modern plans and mechanisms while 
designing new projects. In connection with the educational background of the CEOs and members of board, it is associated with the financial performance of the company. Moreover, it is highly notable that empirical studies highlight on the relationship among CEOs educational level and the performance of the company. The present empirical studies are based on the data collected from the USA, for example, Gottesman and Morey (2006) and Bhagat et al. (2010). These studies provided a poor clue that CEOs holding MBA or higher degree from a prestigious university is linked with outstanding performance. The high-level management of the organization is hired due to their superior capabilities. According to Bhagat et al. (2010), such capability includes observable advantages (educational backgrounds or job experiences) and unobservable ones (leadership or creativity thinking). They stated difficulty in measuring the unobservable characteristics. Also, the observable traits may play an essential role in raising the value of the firm. Hambrick and Mason (1984) also stated that observable characters are interpreted as valid evidence based on their ability and knowledge level, which can affect the decisionmaking process and managerial tactics. According to the upper-management theory, a higher degree of education is closely related with high negotiation and critical thinking skills, open-mindedness, the capability to address information, and acceptance rationally to changes (Hambrick \& Mason, 1984).

\section{Theoretical Review}

The separation between management and ownership in the organization increased the value of corporate governance in the modern organizations. According to O'Sullivan (2000), corporate governance is an exercise to control the resources distribution in a certain corporate. It is a system that shows how these corporate are being guided and managed (OECD, 1999). Rabi (2010) confirmed that a growing concern has been highlighted on observing and evaluating the CEOs and high-level managers by BODs as well as shareholders through corporate governance principles.

The theory of corporate governance roots from the thesis entitled "The Modern Corporation and Private Property" by Berle and Means (1932). The study focuses on major agency problem in contemporary companies where there was segregation amongst management and capital. It was known that modern corporates were suffering from this separation between ownership and management. These corporates were managed by experts in management who are responsible for protecting shareholders' interests. The agency theory and the resource dependency theory are some of the theories that are connected to corporate governance. The resource dependency theory highlighted the function of BOD as a provider of the company, while the agency theory asserted on the BOD function as supervising and controlling the CEOs to ensure that the company's resources are employed for activities like increasing 
investments which may increase a company's value (Hillman \& Dalziel, 2003). Corporate governance was utilized largely as a tool to regulate and direct the decisions of the management. This is due to the separation between ownership and management in the organization; also, it may result in decreasing managerial transparency.

The implementation of corporate governance in companies depends on the degree of theories regarding corporate governance development such as principal-agent and stakeholder theory. The Principal-Agent Theory is the backbone of corporate governance. It assumes that managers acts in a selfish manner and strives for their own interests (Jensen \& Meckling, 1976). This theory is helpful in supplying "a way to explain relations between organizational actors within corporations and external stakeholders" (Coule, 2015). Principal-agent connections appear when investors give resources to corporates, the authorities give powers to corporate's board of directors, and then the boards give power to the executives (Liu, 2012). Furthermore, Stakeholder Theory supported the ideology of CG. Specifically, it defended that corporations have to bolster the social responsibilities of all stakeholders, which are divided into internal and external parties, like local community, employees, suppliers, customers, creditors, and governmental departments. The conflict among these parties may arise due to contradiction, for example, the conflicts between donors' wants and customers'requests (Rochester, 1995). The issue of corporate governance should be stated, and the actions taken according to stakeholders' wants should be involved in the governance structure which is inconsistent with stakeholder theory ( $\mathrm{Hu}, 2012)$. Agency Theory, nevertheless, is imperfect in explaining how managers can treat indirect stakeholders' interests like politicians and what society expects from their companies (Nwabueze \& Mileski, 2008). With its concentration on organizing, control techniques and managerial rules, agency theory left a gap in connection among governance and organization values through stakeholder involvement (Young \& Thyil, 2009). This theory emphasized a control method to CG (Gillan \& Starks, 1998) based on the opinion of corporate governance as a system of regulations, rules, and principles that monitor processes in the organization. In addition, the theory defended a collaborative model. Stewardship theory has evolved as an alternative approach to agency theory, and have obtained greater advocacy (Tian \& Lau, 2001). This, therefore, is because the stewardship theory is close to stakeholder-oriented approach, whereas the agency theory converges to maximize shareholder's value.

Corporate governance encompassed the term of both governance structure and mechanisms (Ma, 2005). Governance structure allocated the rights and tasks between the parties, such as the board of directors, executives, shareholders, employees, financers, and other stakeholders in the organization 
(OECD, 2004). Meanwhile, governance mechanism comprises of the rewards and compensations given to executives and employees to work hard and achieve organizational objectives as well as supervise and control the activities, plans, and decisions. The governance structure is essential if agency problems are permanent and businesses are deficient. Thus, these mechanisms include supervision and election of the shareholders as their agents (Hart, 1995). Subsequently, corporate governance can be interpreted as a mix of solid structure and efficient mechanism (Li, 2000). Solid structure defined the principles of stakeholders and prevailing relationships (Liu, 2007), while efficient governance mechanism displayed how to choose the actions and models to support in carrying out these principles.

\section{Critical Review of Literature}

A study aimed to examine the role of board combination such as gender, age, and nationality of directors based on the level of corporate social responsibility (CSR) disclosures was carried out (Young \& Thyil, 2009). The study used a content analysis technique (panel data) to examine the influence between study's variables. The findings were limited only to the period of 2007 to 2011 with several industries like financial and service sectors. The study revealed great evidence that boardroom diversity has an important role in defining the degree of CSR disclosure. The variables of board diversity consist of independent members, foreign board and woman directors, which showed a positive effect on CSR disclosure in Jordan (Young \& Thyil, 2009).

A relationship between CG and other aspects was found in present literature, especially in board diversity and corporate performance (Fan, 2012). Moreover, many studies are still yet to be handled appropriately. Some of this literature identified that diversity within board members has a great impact on corporate financial performance. Also, few reviews have been conducted to show if this also measures non financial performance (creativity, employees' satisfaction, and customers' loyalty). Consequently, the majority of the studies addressed board diversity widely conducted in the developed countries which are mainly different in terms of its structure and multidimensional contexts from the developing countries. The results of the studies which have been carried out in developed countries may not be suitable and can't be generalized abroad due to complicated and hugely different internal structure for these environments. In a paper that investigates corporate dividend policy and how they can be affected by the quality of corporate governance and board gender diversity, the sample was non-financial firms listed on Amman Stock Exchange in 2009-2015. Three control variables were used in the study (firm size, financial leverage, and return on assets (ROA)). The results revealed that corporate governance quality and board gender diversity have a significant impact on corporate dividend policy. The low 
representation of women in the boardroom was also one of the study results (Al-Rahahleh, 2017). CG quality was also a variable in another study with its influence on cash conversion cycle using industrial firms listed on Amman Stock Exchange in 2009-2013. The paper used three control variables (Sales growth, Firm size, and Net profit). The findings revealed, after using Ordinary Least Square (OLS) regression analysis, that corporate governance quality has a significant negative effect on cash conversion cycle; the study further gave an implication to industrial firms in Jordan for future studies (Al-Rahahleh, 2017).

Furthermore, some of these studies are restricted based on some of the limitations in regards to data collection and analysis like case studies and secondary data of annual reports for firms. It was recommended that the studies should be carried out with several methods like survey and primary data to beautify the results and provide a strong comprehension on the association amongst CG, boardroom diversity, and other factors. Nevertheless, a lot of previous reviews are restricted to only to companies listed in the stock exchange in a particular sector, and exclude other components of the national economy which contains vital business organizations. Empirical reviews on the relationship between board diversity and corporate performance, for example, are debatable with previous researches which demonstrated paradoxical results. Prior evidence also showed mixed and inconsistent findings.

\section{Corporate Governance in Jordan}

The idea of corporate governance involves all universal and local values and rules purposed for the useful and authentic management of an organization. Jordan has applied international codes of corporate governance by including some of these corporate governance codes. These codes involve a lot of guidance in the light of good implementation of CG internationally. The codes were connected to the OECD rules and principles of corporate governance and the directing releases by the Basel Committee to promote the corporate governance codes in national organizations. In general, the recommendations that were linked to these codes were largely supported by those adapted from OECD principles.

The code was divided into different roles and responsibilities which belong to the board of directors, committee responsibilities, disclosure, and rights of stakeholders (Shanikat \& Abbadi, 2011). According to the Jordanian company's law, corporates should be managed by either a general manager or board of directors. These boards should be elected by the shareholders and should take into consideration stakeholders' interests, organization's objectives, and sustainability. The upper management should have a minimum competencies and qualifications to run the company. The law states the size 
of these boards not less than 3 members in order to reinforce their decisions. Also, the CEO is required to run the company with transparency and commitment, and promote ethical and responsible decisions. The board of directors should designate two committees: audit and remuneration committee. This committee is responsible for investigating particular matters and give advice to the board. The company should disclose voluntarily an evaluation of the company's position in a timely manner. This should be done based on all the information that might have a significant effect on the decisions of its stakeholders. Also, the shareholders have voting rights based on the type and amount of shares they have. The company may provide its website or other means of communication to state the shareholders' rights in voting in the general shareholders meeting (Alsharari, 2015; Al-Amarneh, 2014).

Oman et al. (2004) debated that corporate governance in emerging economies has been lately paid much attention to because of the fragility of corporate governance systems in developing markets, which was a key reason for a group of economic collapses which has a significant impact on these markets. Developing economies tend to build improved financial systems involving central banks, local banks as well as stock exchanges. They have less developed systems of accounting, governance, organizing and other financial tools, and less dynamic markets with the most developed infrastructures. These disparities conduced major doubt and also improved the variegation possibilities for shareholders from every country in the world (Kearney, 2012). Tsamenyi et al. (2007) have debated that there were lots of challenges encountering developing countries, involving risk and ambiguity, political turmoil, weak legislative system, vast intervention of government in companies, and low concern of protection for shareholders.

In Jordan, the corporate governance has been classified into a group of segments: a legislative dimension and government surveillance, capital market, disclosure and accounting standards, transparency, dynamic controlling of the board of directors, and protection of properties and minority rights (Khoury, 2003). These classifications were demonstrated in some of the local laws like Company Law in 1997 and Securities Law in 2002. The Jordanian government, through the ministry of trade and industry, attempted to implement these principles through multiple laws and other regulations (World Bank, 2004).

Subsequently, the legislative side has played a significant role in spreading the rules of corporate governance in Jordan through a collection of laws which helps in implementing corporate governance. Also, we can summarize these laws: for example, the Company Law 1997, Securities Law 1997, Banking Law 2000, Insurance Law 1999 and others (Al-Jazi, 2007). Therefore, these laws demand companies to comply with approved 
international rules and standards. Jordan have now agreed and carried out the International Financial Reporting Standards (IFRS) (World Bank, 2004). Additionally, in the 1990s of the last century, the government started a comprehensive reform based on several dimensions to encourage the private sector to be more effective in economic growth and entice more investments through selling some of the valuable assets to this sector in order to manage it (Shanikat, 2007).

The monitoring of the board of directors is of vital importance in corporate governance due to its role in supervision, directing and evaluating the decisions made by the management, and how these decisions correspond with the main objectives and visions for these companies (Gillan, 2006). Some of the law of the articles states that the board of directors is responsible for preparing plans, policies, and guiding the company management. Shareholders that have a minimum of $15 \%$ capital have the right to audit the company's financial records. If they found any corruption or mismanagement, they can sue the BOD and the top management (World Bank, 2004). In Amman Stock Exchange published in 2005 on the Code of Corporate Governance, this code has some chapters and they are divided into certain subjects that contains definitions of some concepts; an introduction of the BOD frame and duties; investors' rights; general meeting for public commission; and financial disclosure guidelines. Moreover, the code is not really mandatory.

A number of codes and rules have a crucial role to play in enhancing corporate governance such as Organization for Economic Cooperation and Development (OECD) principles and Cadbury Report (1992) (Mallin, 2007). Many countries have adopted these principles and Cadbury Report by applying several codes to achieve good practices of corporate governance. These rules attempted to carry out Cadbury Report via providing assortments of recommendation like BOD and ownership structure. Jordan, as well, has agreed and implemented these codes by including them into its own corporate governance guideline in 2006. These standards involve a variety of reference that is consistent with the best implementations in the world (OECD, 2013). However, we can't talk about corporate governance in Jordan without referring to the pivotal and central role of the Central Bank of Jordan, which can't be neglected in developing and raising the awareness on the importance of corporate governance in financial and non-financial industries. The Central Bank of Jordan published a handbook in corporate governance in 2004. In addition, they also prepared the codes of corporate governance which assisted in achieving the world corporate governance activities inside the local commercial banks in Jordan. 


\section{Conclusion}

The current paper reviewed the literature which examined the structure of boardroom and its impact on corporate as a whole. The paper also highlighted some pathway for future studies. Majority of empirical studies exclusively tested the influence of board diversity on firm's financial performance. So, there was a need in the future to conduct a study that investigates the connection between the diversity of board and non-financial performance. In addition, most of the previous reviews have methodological defects like employing a cross-sectional method which are restricted in identifying the causal-effect relationship between boardroom diversity and corporate performance. Therefore, future studies should make use of longitudinal methods to handle this matter. Furthermore, a few attempts have been done in the developing countries on the linkage among board diversity; moreover, the performance of firm did not involve a sampling technique, but it largely makes use of case studies. Thus, there was a limitation in their findings in generalizing it to a wider population. Future studies may explore various studies on the importance of this diversity and its influence in several developing contexts. This review may contribute to the corporate governance stream by providing a comprehensive framework of boardroom diversity advantages. Thus, the benefits of the researchers carrying out future studies are aimed to improve corporate governance environment in national and international context. Finally, the model evolved in this study may be useful for academics purpose to repeat this review in various industries and methodologies or even samples.

\section{References:}

1. Ad Hoc Task Force on Corporate Governance (1999). OECD Principles of Corporate Governance.

2. Al-Amarneh, A. (2014). Corporate governance, ownership structure and bank performance in Jordan. International Journal of Economics and Finance, 6(6), 192-202.

3. Alhazaimeh, A., Palaniappan, R., \& Almsafir, M. (2014). The impact of corporate governance and ownership structure on voluntary disclosure in annual reports among listed Jordanian companies. Procedia-Social and Behavioral Sciences, 129, 341-348.

4. Al-Jazi, O. (2007). Corporate Governance in Jordan', available online at http://www.aljazylaw.com/arabic/pdf/hawkamat_alsherkat2.pdf.

5. Al-Rahahleh, A. S. (2017). Corporate Governance Quality, Board Gender Diversity, and Corporate Dividend Policy: Evidence from Jordan. Australasian Accounting Business \& Finance Journal, 11(2). 
6. Al-Rahahleh, A. S. (2016). Corporate Governance Quality and Cash Conversion Cycle: Evidence from Jordan. International Business Research, 9(10), 140.

7. Alsharari, S. (2015, May). Corporate Governance in Jordan and the Compliance of Public Limited Organisations. In Proceedings of International Academic Conferences (No. 1003668). International Institute of Social and Economic Sciences.

8. Bantel, K. A. \& Jackson, S. E. (1989). Top management and innovations in banking: Does the composition of the top team make a difference?. Strategic management journal, 10(S1), 107-124.

9. Barker III, V. L. \& Mueller, G. C. (2002). CEO characteristics and firm R\&D spending. Management Science, 48(6), 782-801.

10. Barney, J. (1991). Firm resources and sustained competitive advantage. Journal of management, 17(1), 99-120.

11. Berle, A. A. \& Means, G. C. (1932). The modern corporation and private property. New Brunswick. NJ: Transaction.

12. Bhagat, S., Bolton, B. J., \& Subramanian, A. (2010). CEO education, CEO turnover, and firm performance.

13. Cadbury, A. (1992). Report of the committee on the financial aspects of corporate governance (Vol. 1). Gee.

14. Coule, T. M. (2015). Non-profit governance and accountability: Broadening the theoretical perspective. Non-profit and Voluntary Sector Quarterly, 44(1), 75-97.

15. Cox, T. H. \& Blake, S. (1991). Managing cultural diversity: Implications for organizational competitiveness. The Executive, 45-56.

16. Erhardt, N. L., Werbel, J. D., \& Shrader, C. B. (2003). Board of director diversity and firm financial performance. Corporate Governance: An international review, 11(2), 102-111.

17. Fan, P. S. (2012). Is Board Diversity Important for Firm Performance and Board Independence?- An exploratory study of Singapore Listed Companies. The monetary authority of Singapore, 52.

18. Garvey, G. T. \& Swan, P. L. (1994). The economics of corporate governance: Beyond the Marshallian firm. Journal of Corporate Finance, 1(2), 139-174.

19. Gillan, S. \& Starks, L. T. (1998). A survey of shareholder activism: Motivation and empirical evidence.

20. Gillan, S. L. (2006). Recent developments in corporate governance: An overview. Journal of corporate finance, 12(3), 381-402.

21. Gottesman, A. A. \& Morey, M. R. (2006). Does a better education make for better managers? An empirical examination of CEO educational quality and firm performance. 
22. Graham, J. \& Harvey, C. (2002). How do CFOs make capital budgeting and capital structure decisions?. Journal of applied corporate finance, 15(1), 8-23.

23. Habbash, M. (2010). The effectiveness of corporate governance and external audit on constraining earnings management practice in the $U K$ (Doctoral dissertation, Durham University).

24. Hambrick, D. C. \& Mason, P. A. (1984). Upper echelons: The organization as a reflection of its top managers. Academy of management review, 9(2), 193-206.

25. Hart, O. (1995). Corporate governance: some theory and implications. The economic journal, 105(430), 678-689.

26. Hillman, A. J. \& Dalziel, T. (2003). Boards of directors and firm performance: Integrating agency and resource dependence perspectives. Academy of Management Review, 28(3), 383-396.

27. Hu, J. (2012). The Building of NPO Governance mechanism based on principle-agency theory. Hubei Social Science, 4, 39-42.

28. Jensen, M. C. \& Meckling, W. H. (1976). Theory of the firm: Managerial behavior, agency costs, and ownership structure. Journal of financial economics, 3(4), 305-360.

29. Julizaerma, M. K. \& Sori, Z. M. (2012). Gender diversity in the boardroom and firm performance of Malaysian public listed companies. Procedia-Social and Behavioral Sciences, 65, 1077-1085.

30. Kearney, C. (2012). Emerging markets research: Trends, issues, and future directions. Emerging Markets Review, 13(2), 159-183.

31. Khoury, N. S. (2003, September). Institutional control and the continuity of institutions, where does Jordan stand from institutional control. In Proceedings of 5th professional conference, Jordan Association of Certified Public Accountants, Amman (pp. 24-25).

32. Li, W. (2000). The call for the reform practice: The Principle of Chinese corporation governance. China Reform, 10, 23-33.

33. Liu, C. (2007). Research on NPO governance structure. Hubei: Zhongnan University Press.

34. Liu, X. (2012). Research on information transparency of NPO under principle-agency theory-Based on the current situation of charity foundation. Commercial Accounting, 2, 59-60.

35. Ma, L. (2005). Research on the internal mechanism of corporate governance-Practice in China and experience in Japan. Beijing: Higher Education Press.

36. Mallin, C. (2007). Corporate Governance, 2nd Edition, Oxford University Press, Oxford, UK. 
37. Nwabueze, U. \& Mileski, J. (2008). The challenge of effective governance: the case of Swiss Air. Corporate Governance: The international journal of business in society, 8(5), 583-594.

38. OECD, O. E. C. D. (2004). The OECD principles of corporate governance. Contaduríay Administración, (216).

39. OECD. (2013). Jordan - Investment Policy Review - OECD. Available online at: http://www.oecd.org/countries/jordan/jordan-investmentpolicy.htm.

40. Oman, C., Fries, S., \& Buiter, W. (2004). Corporate governance in developing, transition and emerging-market economies.

41. Oman, C. P. (2001). Corporate governance and national development.

42. O'Regan, K., \& Oster, S. (2002). Does government funding alter nonprofit governance? Evidence from New York City non-profit contractors. Journal of Policy Analysis and Management, 21(3), 359379.

43. O'Sullivan, M. (2000). The innovative enterprise and corporate governance. Cambridge Journal of Economics, 24(4), 393-416.

44. Rabi, N. M., Zulkafli, A. H., \& Haat, M. H. C. (2010). Corporate governance, innovation investment and firm performance: Evidence from Malaysian public listed companies. Economia. Seria Management, 13(2), 225-239.

45. Shailer, G. E. (2004). Introduction to Corporate Governance in Australia. Pearson Education Australia.

46. Shanikat, M. (2007). Understanding organisational change in the privatised enterprise: Case study of Jordan Telecom. EBS Review, 22(1), 42-58.

47. Shanikat, M., \& Abbadi, S. S. (2011). Assessment of corporate governance in Jordan: An empirical study. Australasian Accounting Business \& Finance Journal, 5(3), 93.

48. Shleifer, A., \& Vishny, R. W. (1997). A survey of corporate governance. The journal of finance, 52(2), 737-783.

49. Tian, J. J., \& Lau, C. M. (2001). Board composition, leadership structure and performance in Chinese shareholding companies. Asia Pacific Journal of Management, 18(2), 245-263.

50. Tsamenyi, M., Enninful-Adu, E., \& Onumah, J. (2007). Disclosure and corporate governance in developing countries: Evidence from Ghana. Managerial Auditing Journal, 22(3), 319-334.

51. World Bank (2004). 'Report on the observance of standards and codes (ROSC) corporate governance: country assessment Jordan 2004', available online at http://www.worldbank.org/ifa/jor_rosc_cg.pdf

52. World Bank (2013). Jordan Overview. Available online at: http://www.worldbank.org/en/country/jordan/overview. 
53. Young, S. \& Thyil, V. (2009). Governance, employees and CSR: Integration is the key to unlocking value. Asia Pacific Journal of Human Resources, 47(2), 167-185.

54. Zingales, L. (1998). Survival of the Fittest or the Fattest? Exit and Financing in the Trucking Industry. The Journal of Finance, 53(3), 905-938. 